\title{
GLOBAL ECONOMIC RECESSIONS AND THE MARITIME INDUSTRY 1980-2009 IMPACT ON SOUTH AFRICAN SHIPPING 2000-2012
}

\author{
LUNGA JACOBS \\ lungaj@uj.ac.za \\ Department of Transport and Supply Chain Management \\ University of Johannesburg, South Africa
}

\begin{abstract}
The maritime industry is the major enabler of international trade. Major economic events in the international arena such as global recessions affect world trade and therefore the maritime industry as well. South Africa imports and exports major commodities and products therefore such events will also affect the country's economy. This paper explores how different industries within the South African maritime industry have been affected by global economic recessions. As some of them are of great significance to the country's economy, it is imperative to look at how these industries are affected so as to be able to see the national impact.
\end{abstract}

\section{INTRODUCTION}

According to a number of international shipping associations, about $90 \%$ of the world's trade is carried by the international shipping industry. This confirms that shipping is the most used mode to facilitate the movement of goods internationally. Shipping is a multi-billion dollar industry, is globally connected and consists of private and public companies which are either largely funded by banks or privately owned. In both these types of companies, banks and financial markets play a big role. The effects in these financial institutions can be simplified as follows: a change in global economic activity affects global trade. Any change in global trade (commodities) or financial markets affects the shipping industry positively or negatively.

Understanding these effects will also improve the understanding of the reasons for this study as well as the impact of such an event on the shipping industry in a South African context. To get a full understanding of a recession, the fundamental question to ask is: 'What is a recession?' A recession is defined as 'a general decline in economic activity' (Oxford Compact English Dictionary, 1996, s.f. 'recession'). Production as measured by gross domestic product (GDP) normally drops to low levels during a recession. The world economy is cyclical by nature and the cycles are normally determined by what happens in the world's largest economies, namely, the USA, Europe and Asia. Some results of a recession include a decrease in employment, investment, profits and exports. The first recorded recession was in 1779 and there have been many more since then. 
South Africa, being part of the world economy, is heavily dependent on the export of natural resources and other goods to foreign buyers (countries). Exports are also a major contributor to the GDP of the country. This study will seek to explore these trade patterns and figures.

The study will also look at examples of a variety of sectors within the shipping industry and how they have been affected by recessions in its timeframe globally. Industries that will be studied are the:

- motor industry

- container industry (imbalance)

- world seaborne trade

- cruise ship market

It is important to mention that South Africa does not have its own shipping fleet and all discussions concerning the above industries will be approached from an international perspective in the literature review to get an overall understanding of how recessions affect them.

Martin Stopford (1997: 2) points out that if we are to understand the economic and political forces that mould developments in the shipping market we must appreciate the two-way interaction between developments in shipping and the world economy. This is the key objective that the study will seek to project and foster a better understanding thereof in a predominantly South African context.

\section{RESEARCH STRATEGY}

\section{Research approach}

The motivation for this study is two-fold. First, it seeks to uncover the background to the economic downturn within the context of the shipping industry. It will also seek to show how certain sectors within shipping globally and later with specific reference to South Africa, have been affected by recessions as well as the current European financial crisis. The fundamentals of shipping, with particular reference to its cycles are also looked at in this context.

\section{Methods of data gathering}

Various sources and people in different industries such as tourism as well as the motor vehicle export were consulted. Data for the bulk and break-bulk commodities were collected mainly from the Transnet Research Department. Additional graphs have been obtained from various credible sources on the internet as well as the port authority.

\section{Procedure}

The study begins with a brief review of the literature on all four industries under discussion namely motor vehicle, container, cruise ship, bulk and break-bulk commodities. It then 
follows with an in-depth discussion on the abovementioned industries in the context of the South African maritime industry. Various graphs and their interpretations are also provided.

\section{Statistical analysis/treatment of data}

The study has a quantitative as well as a qualitative approach. When addressing the quantitative approach, various graphs and flowcharts will be used to illustrate differences in percentages or totals over the timeframes covered.

Collected data were converted into graphs and interpreted. When looking at the quantitative side, interpretations will be gleaned from the results shown by the graphs. Where data ends in 2010 no additional info could be found.

\section{DISCUSSION}

Since the 1980s, there have been four recessions, namely the 1980s recession, the 1990s recession, the early 2000s recession as well as the 2007 recession. Currently Europe is experiencing an economic crisis due to financial problems in certain European Union member countries. These countries include Portugal, Ireland, Italy, Greece and Spain. France has also increasingly begun to feel the pressure of this economic crisis. The European Commission on Trade confirms South Africa to be Europe's largest trading partner in Africa, with a 26 billion euro import trade total vs a 20 billion euro export trade total. The significance of a shrink in European economic activity will therefore affect South Africa.

\section{The container imbalance}

Since the early 1980s the container has changed the face of shipping. The introduction of containers brought about a faster movement of goods through ports and required less manual labour.

Containers are always in demand when there are economic growth as it results in trade for both imports and exports. When there is an oversupply of containers one side and a shortage thereof on the other side due to demand, it is known as a container imbalance. It is important to ensure there are enough containers available to satisfy, particularly, the export or demand. The container trade has steadily grown over the years despite recessions and is set to grow in the years to come as illustrated in Figure 1. 


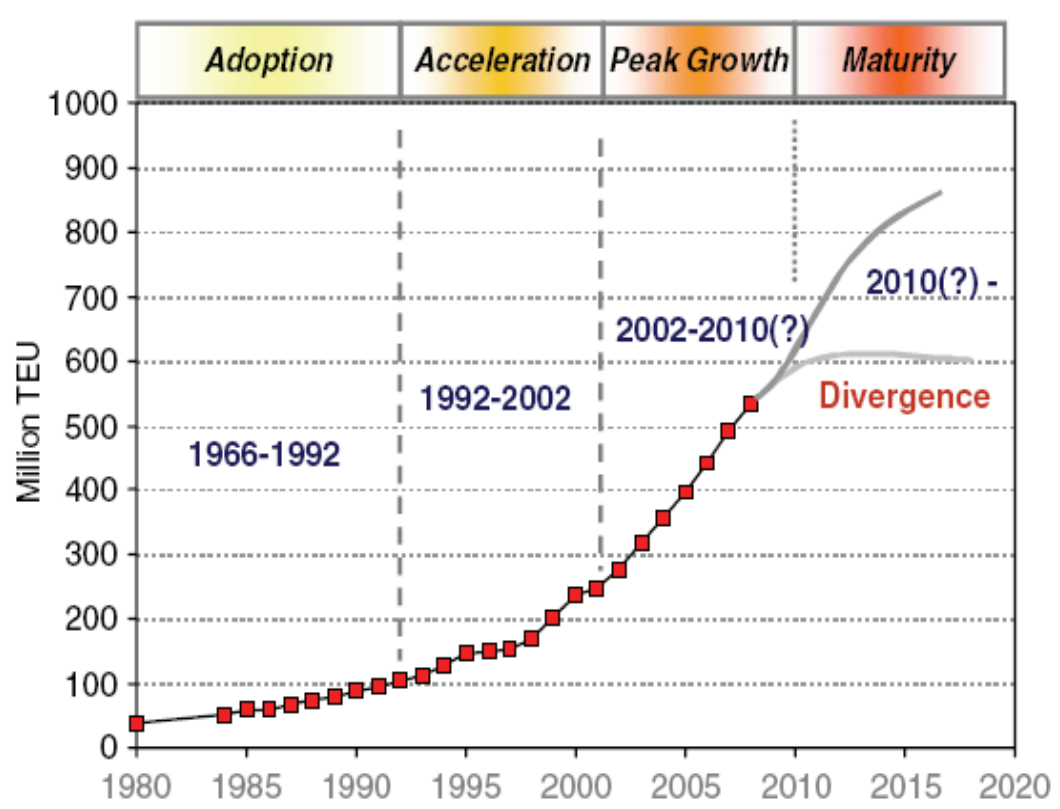

Figure 1: World container traffic, 1980-2008

Cullinane (2004: 231) reports on the size of the Chinese economy and the impact it had on shipping when China joined the World Trade Organisation (WTO). He shows that the waterborne cargo volume carried by ocean shipping reached 2173.27 billion tonne/km. This cargo turnover grew to 2751.06 billion tonne $/ \mathrm{km}$, thus showing the significance of China's contributions to world cargo volumes. Cullinane's study falls short on identifying how the industry was able to meet this growth.

A case study done by Fremont (2007: 436) on Maersk, highlights two systems that have directly influenced the container imbalance. They are the direct port-to-port service as well as the hub-and-spoke network. He highlights the complementary nature of these two approaches and their impact on the maritime industry as they ensured a wider geographical coverage.

The wider geographical coverage is the essence of the imbalance problem as containers tend to drift further from where they are needed. Moving containers to where they are needed becomes costly due to handling and transportation charges. To overcome this, he focuses on the dominance of Maersk through mergers and acquisitions in the 1990s. This enabled the company to enjoy economies of scale through its big container ships which it brought into operation. Another aspect that not only affects empty repositioning but is a result of bigger ships is overcapacity. The introduction of new and bigger ships in 2010 (18 000 TEU vessels) has led to increased overcapacity and the result was the layup of 480 ships mostly in Singapore. This added to the number of those vessels already laid up as a result of the global economic recession. 
Li, Leung, Wu and Liu (2007: 406) seek to answer the problem of how best to deal with the imbalance problem. They confirm that a large number of empty containers have accumulated in import-dominant ports. They also concur that this scenario provides a logistics challenge to the shipping companies to manage and control their containers. They provide different models for decision-makers in companies. These models take different scenarios into account that can be used to make a decision to allocate the right containers at the right time.

A shortcoming in the type of focus by Li et al. (2007: 407) and many other studies is exposed by Dong and Song (2009: 861). They show the highly related nature of the fleet size, and how a large fleet may decrease the requirements to reposition empties. They also highlight various other models and theories other researchers have used in finding solutions to empty repositioning in the vehicle fleet. Another key component of their findings was the fact that these models were most effective in the hub-and-spoke system.

It can be concluded that the hub-and-spoke solution that is normally favoured from a cost perspective in the movement of both full and empty containers should be carefully considered when moving containers. This is particularly more relevant to empty container repositioning as it can add up to high costs. The more dominant companies that have capacity should be better able to survive recessions.

\section{World seaborne trade}

Trade between countries is the main driver of the world economy. These countries trade in goods that vary from single commodities to goods that are sold in bulk. This section of the study will look at how recessions affected world trade, in particular the main commodities such as oil, grain, iron-ore and coal, as well as general goods.

Seaborne trade can be broken down into four different categories namely liquid bulk, dry bulk, general cargo and container cargo. General and container cargo have been discussed in the above section (the container imbalance) and will not be dealt with here. This section will focus mainly on the four main cargoes namely coal, iron ore, grain and oil. The study will also attempt to explore the intricacies of transporting all the above-mentioned commodities.

\section{The different commodities}

A review by Fernley's (quoted by Li et al., 2007, under Marisec.org) provides a picture of the increases and decreases in seaborne trade from 1968-2008 and is shown in Figure 2. 


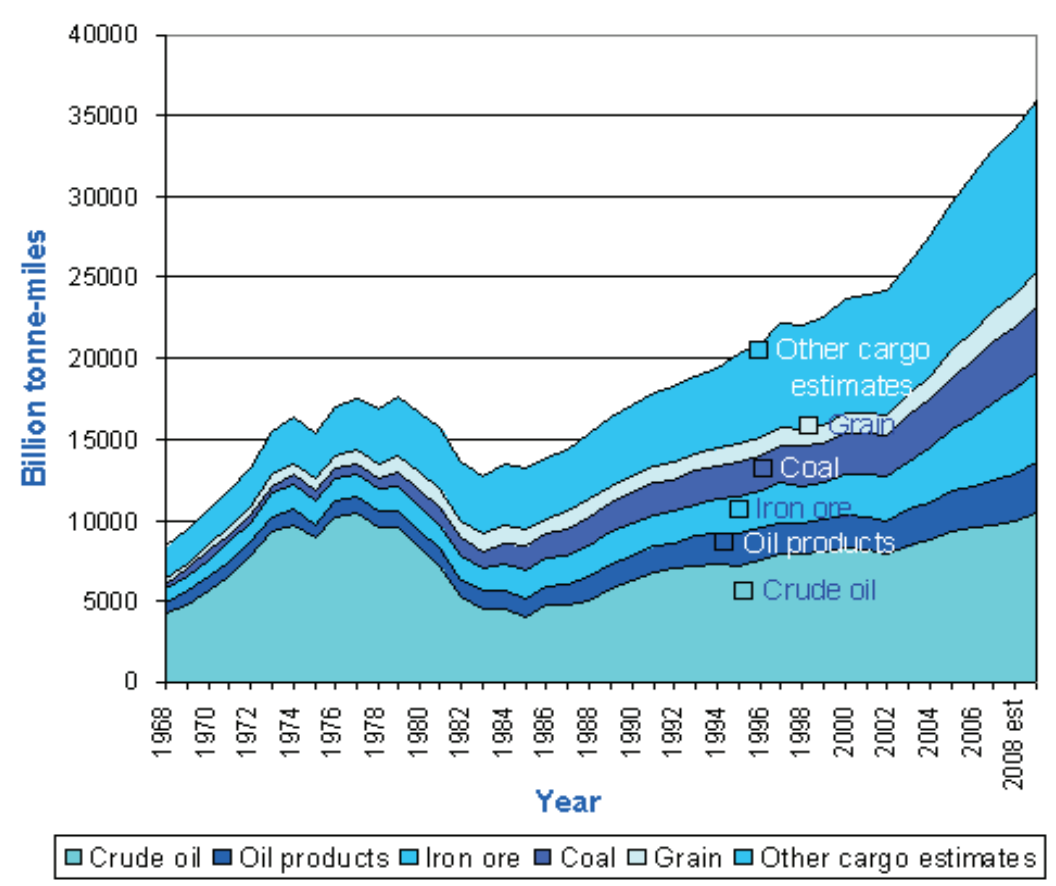

Figure 2: Increases/decreases in seaborne trade

When looking at the graph, the periods to keep in mind are 1980-1982, 1990-1991 and 2001. The 2007 recession will be explained in a graph later on. Fernley's graph gives a clear picture that the first recession in review $(1980,1982)$ was the worst of all recessions. It also seems to have affected all commodities equally as there was a steep decline in trade around 1980. The rest of the recessionary periods, however, show a general increase in trade.

Marisec.org (in Li et al., 2007) confirms this by stating that the last four decades saw trade to have quadrupled from just over 8000 billion tonne miles in 1968 to over 32000 billion tonne-miles in 2007.

When analysing the coal trade, Oczkowski (1998: 60) does an econometric analysis of bilateral trade between Australia and Japan. He explores writings of other researchers on the coal trade since the late 1970s until the 1990s concerning the bilateral monopoly model. This model recognises the presence of other traders but they confirm the importance of savings in transport costs to have facilitated the bilateral trade between the countries mentioned.

Oczkowski (1998) also explores the descriptive qualitative analysis. He sees an anomaly in the trade as Japan gained more, although Australia's position improved later on due to a more concentrated selling structure. The case study provides a framework for the fundamentals of including various macro-economic factors when concluding trade agreements. Secondly, various other factors including transport costs must be included and carefully considered as the prevailing economic climate also affect these costs. The same models can be applied to iron ore agreements and shipments. 
In a study on the transportation of grain, Laulajainen (2007: 219) goes a step beyond just the economic debate when looking at the US trading partners. He analyses the works of Binkley and Harer as well as Park and Koo. They looked at the geographical scale as well as the individual trade routes. In the same article Koo et al., together with Viscencio-Brambilla and Fuller (1984), evaluated what the effects in ocean freight rates, port and canal charges and channel depths might have on US grain exports locally and abroad.

The above research seems to be taking bilateral trade and its negotiations further compared to that provided in models in the coal sector. It also goes beyond just the monetary values, and seeks to cover the areas that add up to the total transport costs but are sometimes neglected.

Oil is by far the commodity that has the highest levels of demand over the last five to six decades. It is an important source of energy. A key factor that also drives this demand is the fact that it is the source of a variety of products. In shipping terms it can be categorised under liquid bulk. At sea it is transported via tankers. Church (2005: 4) confirms the discovery of oil to have peaked in the 1960s where five Middle Eastern countries regained control of the world supply. He identifies Iran, Saudi Arabia and Iraq as the places where two-thirds of the world's total oil reserves are located.

Clarkson's graph in Figure 3 gives a good summary of the pattern of freight rates across the ship types linked to the commodities under discussion.

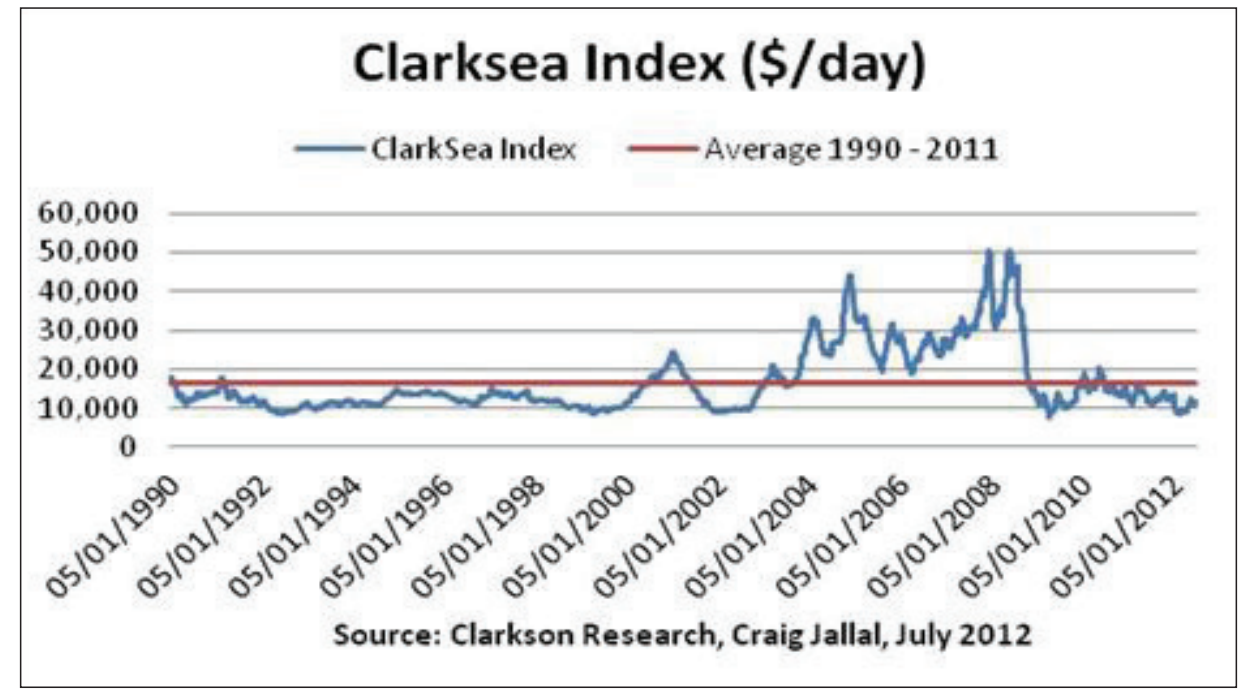

Figure 3: Freight rates on ship types

The graph also includes gas transportation. The graph concludes the discussion by proving that recessions have a direct link to freight rates. Rates dropped during recessions due to a decrease in trade in the four recessions under review. The steepest drop can be seen during the last recession with record low levels. 
The shipping cycle has indeed had a significant impact on the dry bulk market. This has driven freight rates to record highs but also led to volatility of between $\$ 10000$ and $\$ 60000$ per day on the spot market. Further pressure was caused by the introduction of ultra large bulk carriers to service the Far East market. Lloyds estimates the breakeven costs to be just under $\$ 40000$ a day or $\$ 20$ per tonne. New buildings as well as conversions are the key factors that will see the total shift in the sector as a result of the cycle especially from 2013 onwards. It remains to be seen what impact this will all have in light of port and draft restrictions.

\section{The cruise ship industry}

The cruise ship industry has grown over the years but has also been affected by issues outside its ambit. These include recessions and political situations among others. It is also an industry that faces constant inherent risks due to the fact that cruise liners carry a lot of people and valuables.

The industry is driven by people interested in visiting other destinations, hence the tourism perspective. It requires well planned, coordinated and executed supply chain management to ensure on-time arrival of stocks needed. Thus, Veronneau and Roy (2009: 131) describe the cruise ship supply chain as a tourism product and an integral part of the service to the consumer. The industry is linked to tourism and its patterns. Its dependency on a lot of tourism factors as well as things outside the control of those responsible unfortunately also makes it vulnerable if these are not well managed.

Veronneau and Roy (2009: 130) also provide a clear picture of growth expectations by Hall and Braithwaite. They report the industry to have had no end at the time and that the growth experienced beat every expectation as it had enjoyed a sustained annual growth of $8.4 \%$ from 1980-2003. A comparison done on occupancy figures reported a $95 \%$ cruise occupancy figure compared to $59 \%$ for North American hotels.

When Wild and Dearing (2000: 322) looked at the development and prospects for cruising in Europe they identified links between the various shipping markets, tourism and leisure. They identify the cruise market for obvious reasons as the strongest. The summary they give of the time is as follows:

The low market penetration, high levels of satisfaction from cruise tourists with the cruise product and favourable demographics in the key source markets all suggest that continued growth should be possible for the foreseeable future. However, although the industry appears to be recession resistant, as the period between 1993 and 1995 has demonstrated, it can experience falling demand. 
There are mixed views in the literature on the impact of the last major recession particularly with regard to the cruising industry. Cruise News UK (2009), reports an 11\% growth in the UK markets. In numbers it is equal to 1.5 million passengers, a 23\% (577 000) increase.

These numbers look good but there is a reason for this sharp increase despite the recession. A big part of the answer lies in Padget's (2009) article in which he suggests taking a cruise to survive the recession. In it he confirms that cruises on some routes have had a fivefold price cut. One such example is $\$ 50$ per day for a four-day trip from Miami to the Bahamas. In summing up the industry, he cites one of the big cruise companies saying:

The cruise industry barely made it back to port last year. Miami-based Royal Caribbean reported a 98\% drop in fourth-quarter earnings. The winter months, or 'wave season,' are its busiest period; yet onboard traffic at many lines is down at least $25 \%$. But the more important reason cruise lines are desperate to sell tickets is that their real revenue comes not from fares but from onboard spending.

In the same article Padgett (2009) also warns of the effect these price decreases might have in the words of Richard Fain, CEO for Royal Carribean. Fain reckons that filling cabin spaces at the lowest cost is unproductive. He also warns that the lines still have to pay for the introduction of mega ships. Other experts also cautiously suggest that the industry is surviving the recession but warns against certainty in an age of economic turbulence.

It can therefore be concluded that the cruise ship industry also experienced growth during the recessions in focus. The last recession cannot be counted under these as the costs need to be measured. What can be confirmed is that in spite of the growth in numbers during this time, there have been financial losses.

\section{Motor vehicle and shipping industry}

The motor vehicle trade is the backbone of some economies. America and Japan are some of the biggest exporters of vehicles to foreign markets. Transporting vehicles are done by Ro-Ro vessels or via containers. Critical to this industry is the demand for vehicles as they are shipped to where there is a demand. The impact of a downturn can have various negative consequences.

In a report on the drop in automotive exports by Automotive Industries (Shipping lucrative despite drop in exports, 2002: 16), Hiroyuki Maekawa estimated the vehicle export trade to drop to 3.5 million units after the 6.7 million units it peaked at in 1985. Diversification and creativity are what prove to be the rescuers of many industries in distress. An example of this can be seen in a strategy employed by ' $K$ ' Line, a Japanese carrier. Their moves are described as follows by the anonymous author: 
To deal with declining demand, ' $\mathrm{K}$ ' Line has shifted gradually away from pure car carriers (PCCs) to pure car/truck carriers (PCTCs), enabling it to carry a mix of sedans, minivans and SUVs. This has allowed ' $K$ ' Line to raise utilisation, which despite a shrinking export pie still stands at more than 95 percent.

It is a strategy that was to be employed later by other lines in the 2007 global economic recession. In the same article Meakawa also reflects on the impact the declines have on the scheduling of destination port of call. An example is the three-to-seven day delay on the Pacific service between the port of call and the port of discharge. These are delays the operators could ill-afford given the margins.

Politics also plays a major role in the motor vehicle industry. The first case can be seen in the 1980s. Chappell (2007) highlights critical incidents of political involvement by the Reagan Administration to 'restrain' the export of Japanese vehicles to the US.

Katzner and Nikomarov (2005) also examine the impact of political involvement in trade negotiations in their study. Here they take a special look at the trade negotiations between the US and Japan from the 1970s to the 1990s. They confirm that these negotiations yielded nothing to either side for a period of about 25 years. Secondly they also highlight issues of broken promises, strong disagreements, concessions and demands in the failed negotiations.

Hall and Oliver (2005: 279) provide an example of good relationships in the motor vehicle industry that can be established between parties within the car carrier trade. They contend that the nature and structure of the engagement between automobile importers and shipping lines is central to understanding the evolution of the car carrier trade.

They also expose a rarity in many studies not researching linkages between corporate networks (inter-firm partnerships, strategic alliances and supply chain management SCM] etc.) and transport service networks (routing, terminal choice, etc.).

Biederman (2009: 32) reports on a 30\%-40\% decline in automobile shipments on one of the biggest car carriers, Wallenius Wilhelmsen Logistics. He outlines the carrier's plan to lay up 15\%-20\% of its fleet of 65 vessels. Despite this move, as well as that of others within the industry, his major concern is still overcapacity. This is cause for concern as the growth in vehicle export is dependent upon various factors. They include economic growth, oil price, steel price, etc. There needs to be a serious balance between these factors and the volume of vehicles produced together with those imported and exported. Another solution provided by Wallenius Wilhelmsen Logistics was to seek other heavy lift cargo to transport as the automobile sector is in crisis. 
The upswing in vehicle sales only became visible in the late 1990s. Perhaps it is good reason for the shipping industry to consider that vehicle export volumes take time as was proven in this early 1990 s recession.

\section{THE SOUTH AFRICAN SHIPPING INDUSTRY}

In competitive markets, like container shipping, any prolonged imbalance in cargo flows tends to influence the pricing of the competing lines resulting in higher prices charged on cargo flowing in the dominant direction. Lower prices are charged for cargo moving as part of the lower flows. In South Africa containerised import cargo flows, with the exception of a few short periods, have been dominated by inbound flows resulting in higher average rates on imported cargo.

\section{The container imbalance}

Imbalances in containerised cargo flows impact negatively on the profitability of shipping lines. It necessitates the positioning of empty containers. The impact of the cost of repositioning on profits is smaller if the cost is incurred to provide containers for higherrated import cargoes. The impact is severe should containers have to be positioned for low-rated export cargo. It is usually not commercially viable to provide additional vessel capacity to cater for export-dominated trades.

Figure 4 takes a look at the trend in containerised cargo flow in South Africa for the last eleven-and-a-half years.

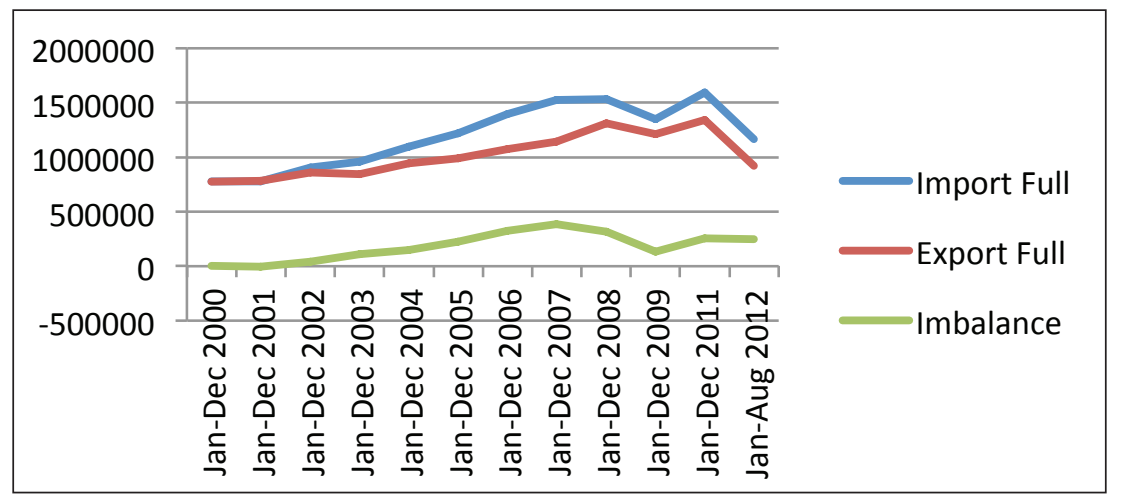

Figure 4: Containerised cargo flows

\section{Historic containerised cargo flows}

The actual flows during the period March 2001 to December 2009 show the following growth rates:

- Historic containerised import flows were $9.9 \%$ per annum versus the $2.8 \%$ per annum expected towards the end of 2001. 
- Historic containerised export flows were $5.4 \%$ per annum versus the $5.7 \%$ per annum expected towards the end of 2001.

This leaves the import-dominated imbalance well intact.

The question for the next decade is 'Can growth in import flows maintain a rate of more than 5\% per annum?' Export growth may well achieve that level of growth. It has the 5.5\% level for all ten-year periods since January 1995.

It can also be concluded that the current economic crisis in Europe certainly does have an impact on current import as well as export volumes as a result of a decline in both. Due to certain shortcomings in the statistics received from the Ports Authority, despite a recheck, the statistics received were used by taking two overlapping years and average tonnes per TEU.

\section{The motor vehicle industry}

According to the National Association of Automotive Components and Manufacturing (NAACAM), the South African automotive industry consists of light vehicle assemblers, the medium and heavy commercial vehicle sector, the component sector and the retail sectorthe latter including motor trade and aftermarket parts and accessories. It further states that the catalytic converter manufacturing industry in South Africa is the biggest contributor to the automotive component export sector.

The authority on vehicle manufacturing and sales in South Africa is the National Association of Automobile Manufacturers of South Africa (NAAMSA). These two associations (NAACAM and NAAMSA) are therefore the two bodies that drive the industry particularly regarding vehicle and parts exports. All vehicle exports are shipped out of South Africa to various destinations across the world. Figure 5 illustrates vehicle exports for the period 2000-2011 (with projected figures for 2012 and 2013). It shows three vehicle types, namely cars, light commercial vehicles (LCV) as well as medium and heavy commercial vehicles (HCV).

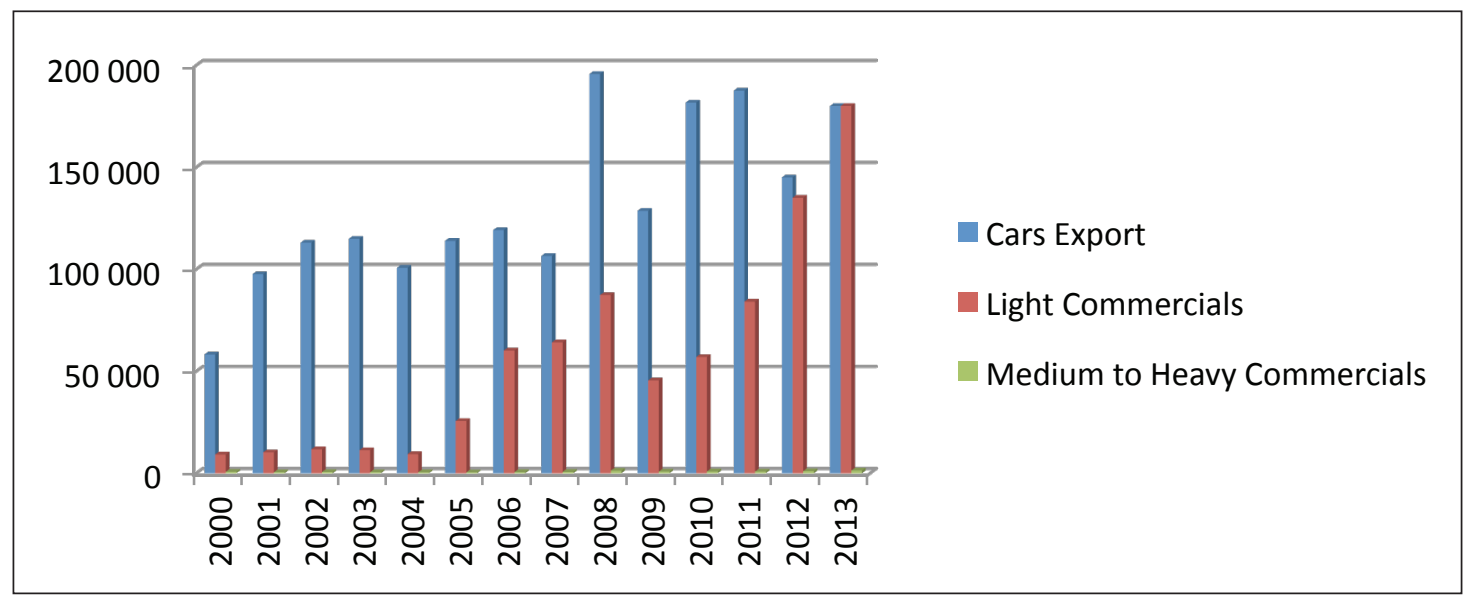

Figure 5: South African export motor vehicle figures 
Compared to the rest of the world motor industry the South African automotive industry was not severely affected by the recession. Looking at the graph, the car sector, which has always been the strongest, was affected in 2009. It was, however, higher than all the previous years since 2000 except 2008.

A comparison between 2008 and 2009 shows a decrease. The difference in units sold over the two years is seen when looking at the annual GDP growth rate as per the annual GDP changes in market prices. Here 2009 shows the lowest figure $(-1.5 \%)$ over the period since 2000 with the average over the same term being 4.2\%. The final analysis shows that 2000 and 2009 were the years that the industry had the lowest figures compared to other years. Despite the economic recession vehicle sales continued to grow from 2009-2011. As per the data provided by NAAMSA, the 2012-2013 figures still provide for optimism in the industry.

\section{Bulk imports}

The early 2000 recession statistics show that imports have remained constant since the late 1990s to December 2001. A concern is the sudden rise in volumes in early 2001 as well as a sudden drop to the same levels experienced earlier. As South Africa's main bulk imports are normally liquid bulk there might have been a rush to stock up on reserves in anticipation of the recession. Despite fluctuation, imports started rising and remained on a plateau until the second half of 2007. This phenomenon is in line with world economic growth experienced elsewhere. From 2007 it dropped to levels similar to those seen earlier.

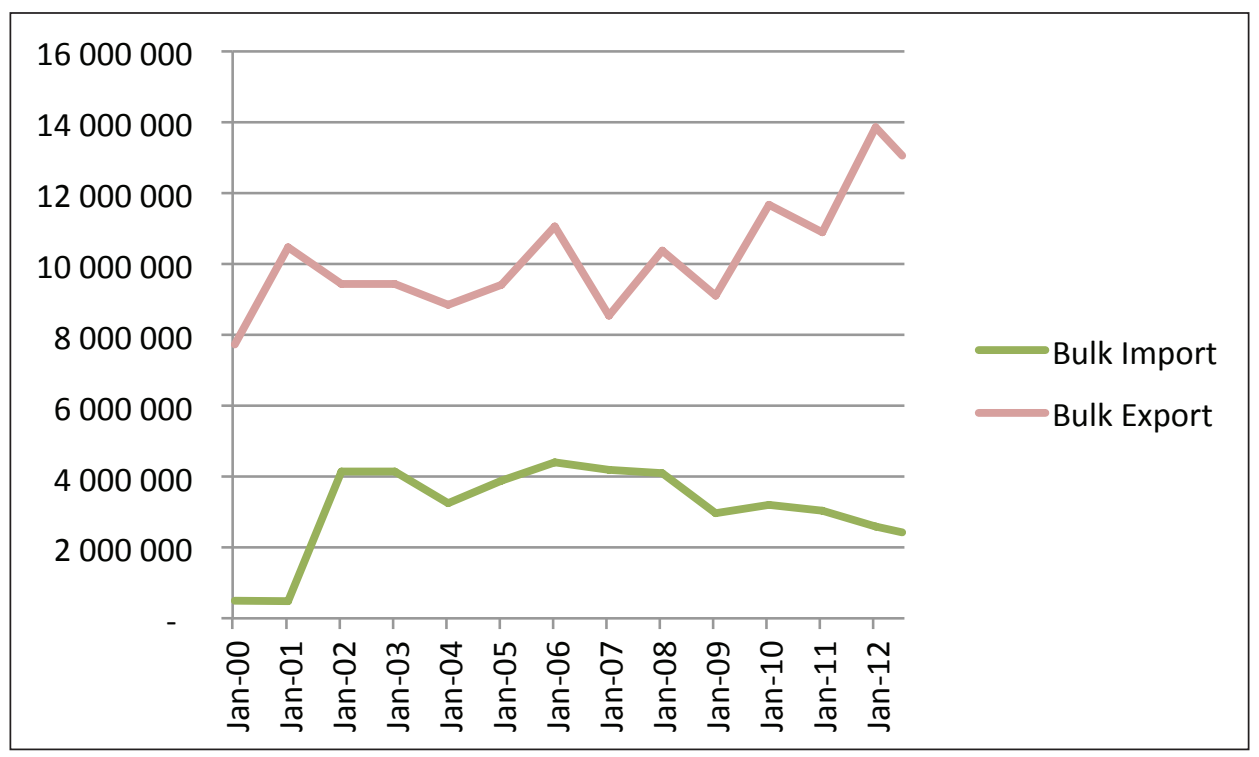

Figure 6: Bulk imports and exports per year

\section{Bulk exports}

The graph in Figure 6 shows that bulk exports were much more fluctuating than imports in the early 2000s. The South African economy is heavily dependent on these exports in 
the form of coal, iron ore, grain and platinum, with China being its biggest trade partner. A similar picture to imports emerges when looking at exports as there was a huge decline in exports in the middle of 2001. According to Business Report (2009), export trade volumes have shrunk by $19.2 \%$ year after year due to the recession. The bigger picture shows trade having increased over the last decade from R144.9 billion to R663.099 billion.

The South African dry bulk market is dominated by two commodities, namely iron ore and coal. These are exported via the Port of Saldanha (iron ore) as well as the Port of Richards Bay (coal). Both these lines have seen major challenges in terms of capacity constraints. The volume declines after 2007 are not only attributed to economic climates. Due to capacity constraints as well as work done to boost volumes on both lines, volumes have also been negatively impacted. The coal line has for example seen record low declines of 61 million tonnes before increasing to 68 million tonnes in 2011. It is also projected to reach 90 million tonnes in the near future. The Iron Ore (Orex) line set a new record of 45 million tonnes in 2010, then 53 million tonnes in 2011, with a target of 80 million tonnes in the near future.

The current decline can however mainly be attributed to the market.

\section{Break-bulk imports and exports}

Compared to bulk cargo, break-bulk has, over the years in review, been far more consistent in both imports and exports. Although exports are slightly higher in terms of volumes, the pattern has remained relatively similar when looking at the two graphs in Figures 7 and 8 . There is doubt around the sudden spike and huge subsequent drop for both import and exports halfway through 2002.

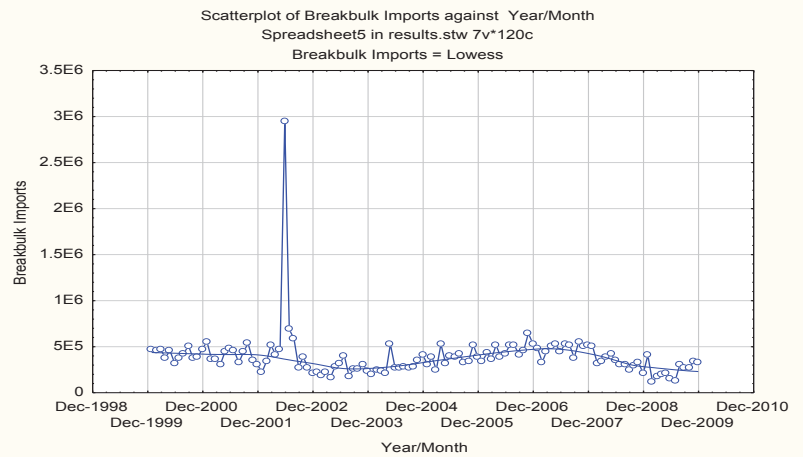

Figure 7: Break-bulk imports per year

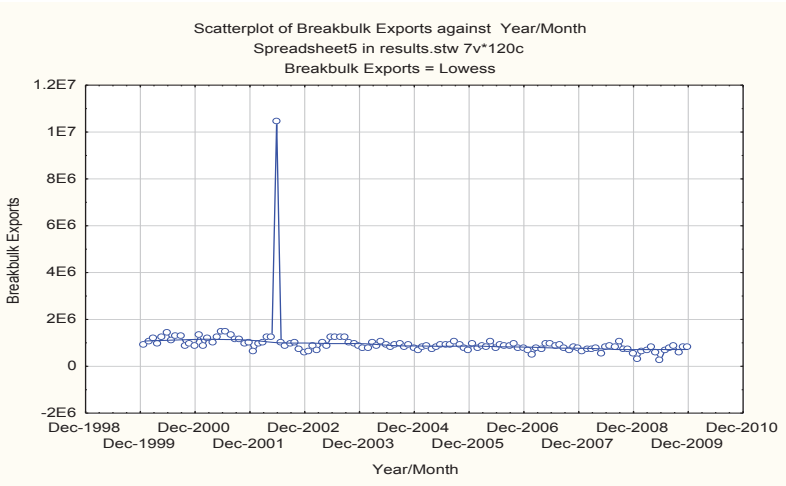

Figure 8: Break-bulk exports per year

Break-bulk imports and exports have roughly maintained the same average levels over the last $8-10$ years. What is not indicated on the graph are the figures for 2010 to the present, which are as follows:

- Jan 2010-August $2012=13075136$ tonne (imports)

- Jan 2010-August $2012=37955878$ tonne (exports) 


\section{The cruise ship industry}

Tourism has various facets and the cruise ship industry is what links it to shipping. South Africa has, over the last decade, again become a destination of choice for some cruise ships.

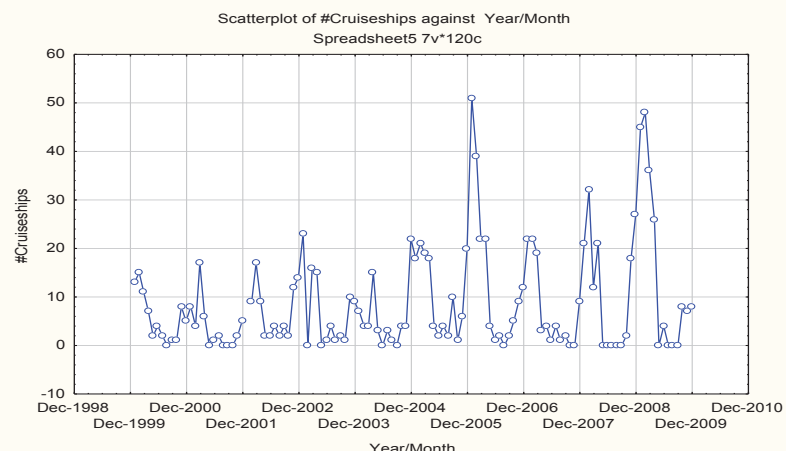

Figure 9: Cruise ships visiting SA ports

From Figure 9 it is evident that these industries are largely seasonal as most port calls happen at a specific time of year due to the weather and seasons. In both recessions over the period in focus there has been a decrease in the number of ships calling at South African ports. The highest numbers recorded (50 in 2005, 48 in 2008) also indicate that the industry is recovering.

\section{CONCLUSION}

The South African maritime industry forms part of the mainstream economy and is a big contributor to its success. As with all things, negativity in the economy will invariably affect the maritime industry and vice versa. To get the full perspective of the impact of the recession on the maritime industry, one has to look at all the industries discussed separately and see how they are affected. It can be concluded that those industries, as far as maritime is concerned, that were the hardest hit by the recession are the bulk export market and the motor vehicle industry.

The South African economy is commodity-based and as such bulk exports in particular play a major role. Secondly, this sector is also highly dependent on international trends and demands, particularly the coal and iron ore sector.

Commodity prices are invariably also determined by their markets. Despite the difficulty, an example of potential growth can be seen at the Port of Saldahna, where it has managed to secure contracts to the tune of 49 million tonnes for the 2010-2011 financial year (Davenport, 2010). Iron ore exports saw a rise despite the recession. The coal sector in many ways has seen a decline globally during this time. This enforces the idea that there should 
be diversity in bulk exports in order to cushion the economy in the event of a recession. Secondly, crucial to the anticipation of growth or decline, is the issue of expansion. With the creation of capacity to increase volumes, the emphasis of both Transnet Freightrail as well as the Ports Authority, should be on efficiency. This will certainly take South African exports to the next level.

The motor vehicle industry has suffered record lows and like its overseas counterparts, drew government intervention. There was, however, no financial intervention. Data provided by NAAMSA's latest data provide a clear picture on the industry and is set to be stable in spite of a mini decline.

Container trade on the other hand was less affected and to the contrary showed increases for both imports and exports during 2009. Unlike some European, Asian and American ports, South African ports experienced a balanced container trade year, ensuring a 'stable' imbalance.

It is, however, something that always needs to be kept in mind, as it can have negative consequences on the container trade for South Africa as well as the region. The bigger lines can learn a valuable lesson as an imbalance from a cost perspective has negative cost implications for them. Constant monitoring and checking of container stocks is therefore necessary.

Break-bulk on the other hand seems to be the industry that had 'better times' during the recession. Against the backdrop of Africa's development it offers immense opportunities. Evidence for this can be seen in the fact that despite decreases in trade with the rest of the world, trade with Africa was not affected negatively comparatively speaking. Opportunities to be taken are plentiful, particularly by South Africa as it has the necessary infrastructure and resources to supply and move goods. A stronger claim needs to be staked in discussion in the Southern African Development Community (SADC) as well as the Economic Community of West African States (ECOWAS). The latter is of particular significance due to the developments in oil explorations taking place on the West African coast.

\section{The final industry over which very little or nothing can be done during a recession is} the cruise ship industry. As much as it is a lucrative tourism revenue mechanism, cruise ships decide on which ports to call in for various reasons. Paramount to these reasons is favourable weather, safety and security. Threats to safety and security are of particular significance if one takes for example the Somali Pirates operating in as well as outside their waters. Revenue that could have been earned in a year when cruising prices were at record lows to attract customers was lost. So too is the revenue that ports could have earned. 
It can therefore be concluded that the South African maritime industry (in the sectors discussed) was indeed affected by the 2009 global economic recession. It has however survived it in much better ways than its overseas counterparts. Having done so it can be also be concluded that the current economic crisis in Europe will certainly affect it but not at the levels seen in earlier times of economic decline.

It managed this in part due to the size, strength as well as policies of the South African economy. When looking at the origins of this past recession a key lesson has to be learnt. All sectors must work at playing within the rules of their respective games, with an eye on what happens in the other, thus avoiding potential catastrophes. 


\section{REFERENCES}

Biederman, D. 2009. Automobile carriers rethink services and junk ships, keeping scrap yards busy. Journal of Commerce, 20 April: 32-33.

Business Report. 2009. China takes top spot in 2009 SA export stakes. [Online] Available: http://www.busrep.co.za/index.php?from=rss_\&fArticleld=5181747 [25 March 2010].

Chappell, L. 2007. Would the Toyota system work in the US? Automotive News. 29 October, (82):84-89. Church, N. 2005. Why our food is so dependent on oil. Powerswitch [Online]. Available: http://www.powerswitch.org.uk/portal/index.php?option=content\&task=view\& id=563 [19 April 2009].

Clarkson's graph in http://shippingresearch.wordpress.com/2012/07/05/the-clarksea-indexthe-heart-rate-monitor-of-the-shipping-industry/ [20 September 2012].

Cruise News UK. 2009. What is the growth rate of the cruise industry? [Online] Available: http://cruise-news.org.uk/growth-rate-cruise-industry/ [2 October 2009].

Cullinane, K. 2004. The container shipping industry and the impact of China's ascension to the WTO. Research in Transportation Economics, 12(1):221-45.

Davenport, J. 2010. Saldanha iron-ore bulk terminal expansion to be completed in June 2010. [Online] Available: http://www.http://www.engineeringnews.co.za/article/saldanhabulk-iron-ore-terminal-expansion-to-be-completed-in-june-2011-2010-04-16 [10 May 2010]

Dong, J.-X. \& Song, D.-P. 2009. Container fleet sizing and empty repositioning in liner shipping systems. Transportation Research Part E: Logistics and Transportation Review, 45(6):860-77.

Fremont A. 2007. Global maritime networks, the case of Maersk. Journal of Transport Geography, 15(6):431-42.

Hall, P.V., \& Oliver, D. 2005. Inter-firm relationships and shipping services: the case of car carriers and automobile importers to the United States. Maritime Policy \& Management, 32(3):279-95.

Katzner, D.W. \&, Nikomarov, M.J. 2005. Exercises in futility: Post-war automobile-trade negotiations between Japan and the United States. Department of Economics, University of Massachusetts, Amherst. Working paper 2005-16. [Online] Available: http://scholarworks. umass.edu/econ_workingpaper/52/ [22 August 2012]. 
Laulajainen, R. 2007. Dry bulk shipping market inefficiency, the wide perspective. Journal of Transport Geography, 15(3):217-24.

Li, J.-A., Leung, S.C.H., Wu, Y., \& Liu, K. 2007. Allocation of empty containers between multi-ports. European Journal of Operational Research, 182(1):400-12. http://www.marisec. org/worldtradeflyer.pdf [2 September 2010]

Oczkowski, E. 1998. An econometric analysis of the bilateral monopoly model. Economic Modelling, 16(1):53-69.

Padgett, T. 2009. How to save in the recession? Take a Cruise. Time [Online]. Available: http://www.time.com/time/travel/article/0,31542,1881316,00.html. [24 February 2009].

Shipping lucrative despite drop in exports. 2002. Automotive Industries, 182(10):16.

Stopford, M. 1997. Maritime Economics. 2nd ed. London: Routledge.

Veronneau, S., \& Roy, J. 2009. Global service supply chains: An empirical study of current practices and challenges of a cruise line corporation. Tourism Management, 30(1):128-39.

Wild, P., \& Dearing, J. 2000. Development of and prospects for cruising in Europe. Maritime Policy \& Management, 27(4):315-33.

\section{Table of acronyms}

\begin{tabular}{|l|l|}
\hline ECOWAS & Economic Community of West African States \\
\hline GDP & Gross Domestic Product \\
\hline HCV & heavy commercial vehicles \\
\hline LCV & light commercial vehicles \\
\hline NAACAM & National Association of Automotive Components and Manufacturing \\
\hline NAAMSA & National Association of Automobile Manufacturers of South Africa \\
\hline PCC & pure car carriers \\
\hline PCTC & pure car/truck carriers \\
\hline SADC & Southern African Development Community \\
\hline SCM & Supply Chain Management \\
\hline WTO & World Trade Organisation \\
\hline
\end{tabular}

